\title{
Strategi Peningkatan Kapasitas UMKM melalui Program Pemberdayaan di Wilayah Jakarta Timur
}

\section{(Capacity Building Strategy of SMEs through Empowerment Program in East Jakarta Area)}

\author{
Ade Maya Kartini' ${ }^{1}$, Belinda Febri Patricia², Edo Bagasunanda ${ }^{3}$, Muhammad Farhan Muzakki ${ }^{4}$, \\ Muhammad Syauqi Baihaqi ${ }^{5}$, Nurlia Mahmudah6, Rafii Marlano7, Stacia ${ }^{8}$, Lindawati Kartika7 ${ }^{*}$ \\ ${ }^{1}$ Departemen Matematika, Fakultas Matematika dan Ilmu Pengetahuan Alam, Institut Pertanian Bogor, \\ Kampus IPB Dramaga, Bogor 16680. \\ 2 Departemen Ilmu Produksi dan Teknologi Peternakan, Fakultas Peternakan, Institut Pertanian Bogor, \\ Kampus IPB Dramaga, Bogor 16680. \\ 3 Departemen Manajemen Hutan, Fakultas Kehutanan, Institut Pertanian Bogor, Kampus IPB Dramaga, Bogor 16680. \\ ${ }^{4}$ Departemen Ilmu Ekonomi Syariah, Fakultas Ekonomi dan Manajemen, Institut Pertanian Bogor, \\ Kampus IPB Dramaga, Bogor 16680. \\ ${ }^{5}$ Departemen Hasil Hutan, Fakultas Kehutanan, Institut Pertanian Bogor, Kampus IPB Dramaga, Bogor 16680. \\ ${ }^{6}$ Departemen Biokimia, Fakultas Matematika dan Ilmu Pengetahuan Alam, Institut Pertanian Bogor, \\ Kampus IPB Dramaga, Bogor 16680. \\ 7 Departemen Manajemen, Fakultas Ekonomi dan Manajemen, Institut Pertanian Bogor, Kampus IPB Dramaga, \\ Bogor 16680. \\ ${ }^{8}$ Departemen Ilmu dan Teknologi Pangan, Fakultas Teknologi Pertanian, Institut Pertanian Bogor, \\ Kampus IPB Dramaga, Bogor 16680. \\ *Penulis Korespondensi: linda@apps.ipb.ac.id \\ Diterima September 2020/Disetujui Juni 2021
}

\begin{abstract}
ABSTRAK
Salah satu sarana pengabdian dalam meningkatkan ekonomi masyarakat adalah Kuliah Kerja Nyata Tematik Institut Pertanian Bogor (KKN-T IPB). Peran mahasiswa sangat penting dalam meningkatkan ekonomi masyarakat melalui program KKN-T IPB, terutama dalam situasi pandemi COVID-19 yang berakibat kepada dibatasi dan ditutupnya berbagai macam sektor usaha. Pengabdian masyarakat ini bertujuan untuk meningkatkan soft skill masyarakat dalam hal ini Usaha Mikro dan Kecil (UMK) sehingga dapat tetap bersaing dan meningkatkan skala usahanya di Kecamatan Jatinegara, Kota Administrasi Jakarta Timur. Metode yang digunakan dalam pengabdian masyarakat ini adalah dengan pelatihan secara langsung di Aula Kantor Kecamatan Jatinegara dan secara daring melalui media teleconference zoom. Pelatihan yang dilaksanakan yaitu, pelatihan pencatatan keuangan; pelatihan foto produk, desain canva, dan instagram; pelatihan pemasaran digital; pelatihan packaging makanan; dan webinar pengelolaan keuangan. Hasil pelatihan menunjukkan bahwa UMK di Kecamatan Jatinegara memahami materi yang diberikan dalam setiap pelatihan, mendapatkan manfaat dari pelatihan yang diberikan, dan isi pelatihan sesuai dengan usaha yang dijalani oleh setiap peserta.
\end{abstract}

Kata kunci: KKN-T, mahasiswa, pelatihan UMK

\begin{abstract}
One of the means of community service in improving the economy is the Thematic Real Work Lecture at the Bogor Agricultural University (KKN-T IPB). Students play very important role in improving the community's economy through the KKN-T IPB's programs, especially in the COVID-19 pandemic situation which results in the limitation and closure of various business sectors. This community service aims to improve the soft skills of the community in this case Small and Micro Enterprises (SMEs) so that they can remain competitive and increase the scale of their business in Jatinegara District, East Jakarta Administrative City. Methods used in this community service is by training directly in the Jatinegara District Office Hall and online through the zoom teleconference media. The training carried out (training that has been held) namely, financial recording training; product photo training, design training using Canva and Instagram; digital marketing training; food packaging training; and financial management webinars. The results of the training show that MSEs in Jatinegara District understand the material provided in each training, benefit from the training, and the training content well-suited with the business undertaken by each participant.
\end{abstract}

Keywords: KKN-T, students, SMEs training 


\section{PENDAHULUAN}

Kuliah Kerja Nyata Tematik Institut Pertanian Bogor (KKN-T IPB) merupakan salah satu sarana bagi mahasiswa untuk menerapkan ilmu pengetahuan yang telah didapat di dunia perkuliahan untuk membantu menyelesaikan permasalahan yang terjadi di masyarakat. KKN-T ini juga dapat menjadi wadah bagi mahasiswa untuk meningkatkan kemampuan kerja sama dengan tim, kerja sama dengan orang yang berbeda latar belakang, dan meningkatkan kemampuan leadership. Pandemi Covid-19 membuat Institut Pertanian Bogor menerapkan kebijakan KKT-T domisili.

Coronavirus adalah virus RNA dengan ukuran partikel 120-160 nm. Virus ini utamanya menginfeksi hewan, termasuk di antaranya adalah kelelawar dan unta (Susilo et al.2020). Wabah Corona Virus Disease 2019 (Covid-19) pertama kali dilaporkan sebagai kasus yang serupa dengan penyakit pneumonia karena gejalanya yang mirip di Wuhan, Provinsi Hubei. Gejala tersebut dapat berupa demam dan batuk/pilek/nyeri teng-gorokan/sesak. Namun, penelitian menunjukkan bahwa sampel Covid-19 yang diteliti memiliki etiologi coronavirus baru yang menyebabkan penyakit pernapasan pada manusia (Ren et al. 2020). Covid-19 mulai menyebar di Indonesia pada awal Maret 2020 sejak Presiden meng-umumkan kasus pertama di Depok, Jawa Barat. Hal ini menyebabkan kekhawatiran dan ke-panikan di seluruh lapisan masyarakat. Wabah Covid-19 terus menyebar hampir ke seluruh wilayah di Indonesia terutama Provinsi DKI Jakarta yang menjadi epicentrum atau pusat penyebaran Covid-19. Menurut Kemenkes RI (2020) dalam Susilo et al. (2020), data kasus Covid-19 yang terkonfirmasi berjumlah 1.528 kasus dan 136 kasus kematian per tanggal 31 Maret 2020. Tingkat mortalitas Covid-19 di Indonesia sebesar 8,9\%, angka ini merupakan yang tertinggi di Asia Tenggara (WHO 2020 dalam Susilo et al. 2020).

DKI Jakarta merupakan Ibu Kota Indonesia yang memiliki jumlah penduduk sekitar 10.5 juta jiwa pada tahun 2019 (BPS 2020). Kasus Covid19 yang terus meningkat disebabkan oleh penyebaran virus Covid-19 yang cepat dari manusia ke manuasia melalui droplet yang keluar saat batuk atau bersin oleh si penderita atau pasien (Han \& Yang 2020). Selain itu, virus ini juga mampu bertahan di udara (aerosol) selama minimal tiga jam dan pada permukaan benda dalam rentang waktu yang berbeda, misalnya pada benda dengan permukaan plastik dan stainless steel ( $>72$ jam) dan kardus (24 jam) (Doremalen et al. 2020). Hal tersebut membuat pemerintah Provinsi DKI Jakarta per tanggal 10 April 2020 menerapkan kebijakan Pembatasan Sosial Berskala Besar (PSBB) sebagai upaya memutus rantai penularan Covid-19. Selain itu, pemerintah dan lembaga dunia seperti WHO juga memeringatkan pentingnya menjaga kebersihan, seperti selalu mencuci tangan dengan sabun selama 20 detik, menggunakan masker saat beraktivitas di luar ruangan, dan menghindari kontak langsung antar manusia.

Salah satu wilayah zona merah penyebaran Covid-19 di Provinsi DKI Jakarta adalah Kecamatan Jatinegara (Diskominfotik Jakarta 2020). Kecamatan Jatinegara merupakan salah satu kecamatan di Kota Administrasi Jakarta Timur yang memiliki luas wilayah $10,25 \mathrm{~km}^{2}$. Luas wilayah tersebut merupakan $5,45 \%$ luas wilayah Kota Administrasi Jakarta Timur dengan luas 188,03 $\mathrm{km}^{2}$, terdiri atas 8 kelurahan, yaitu Kelurahan Bidara Cina, Cipinang Cempedak, Cipinang Besar Selatan, Cipinang Muara, Cipinang Besar Utara, Rawa Bunga, Bali Mester, dan Kampung Melayu. Jumlah rukun warga (RW) dari 8 kelurahan tersebut terdapat 91 RW dan 1125 Rukun Tetangga (RT) dengan jumlah penduduk 321.396 (BPS 2019). Kawasan Jatinegara dikenal sebagai pemukiman yang padat dan perdagangan yang ramai. Perkembangan sarana transportasi membuat kawasan Jatinegara berkembang secara ekonomi sebagai kawasan perdagangan utama selain Glodok, Pasar Senen, dan Tanah Abang (Kurniawan et al. 2018). Kecamatan Jatinegara juga merupakan pusat perbelanjaan dan jasa atau dikenal dengan Kawasan Segitiga Jatinegara yang terdiri dari Pasar Batu Akik dan Permata yang terletak di sebrang Stasiun Jatinegara dan Pasar Mester (Jonathan et al. 2019).

Pemberlakuan PSBB selama pandemi Covid19 yang terjadi di tahun 2020 memberikan dampak yang besar bagi masyarakat khususnya dalam bidang ekonomi, misalnya banyak masyarakat yang terkena Pemutusan Hubungan Kerja (PHK) dan pendapatan Usaha Mikro Kecil Menengah (UMKM) yang menurun. Melihat besarnya luas wilayah dan banyaknya penduduk di Kecamatan Jatinegara, menjadi perhatian bagi tim KKN-T Kecamatan Jatinegara untuk membuat program yang dapat berkolaborasi dengan pemerintah Kecamatan Jatinegara untuk penanggulangan Covid-19 dan meningkatkan potensi masyarakat Jatinegara, terutama yang bergerak di bidang UMKM bagian pangan melalui metode 
pengabdian. Program yang dilaksanakan oleh tim KKN-T IPB Kecamatan Jatinegara bertujuan memberikan edukasi kepada masyarakat dalam aspek kesehatan khususnya untuk menurunkan kasus positif Covid-19 dan membantu masyarakat dalam aspek ekonomi khususnya untuk meningkatkan keterampilan para pelaku UMKM. Adapun tujuan kegiatan ini adalah meningkatkan soft skill masyarakat dalam hal ini Usaha Mikro dan Kecil (UMK) sehingga dapat tetap bersaing dan meningkatkan skala usahanya di Kecamatan Jatinegara, Kota Administrasi Jakarta Timur.

\section{METODE PELAKSANAAN KEGIATAN}

\section{Lokasi dan Partisipan Kegiatan}

Webinar strategi mengelola UMKM dalam membangun daya saing berkelanjutan dilakukan secara online dengan aplikasi zoom. Sementara untuk kegiatan pelatihan pencatatan keuangan, pelatihan foto produk, canva, dan instagram, pelatihan pemasaran digital, dan pelatihan packaging makanan dilakukan di Aula Kecamatan Jatinegara. Kagiatan kampanye new normal dan stop penggunaan kantong plastik bertempat di Pasar Bali Mester, Pasar Rawa Bunga, dan Jalan Cipinang Jaya Raya. Partisipan yang mengikuti kegiatan adalah sebanyak 60 pelaku UMKM di Kecamatan Jatinegara dan pedagang/UMKM dan konsumen di Pasar Bali Mester, Pasar Rawa Bunga, dan Jalan Cipinang Jaya Raya.

\section{Alat dan Bahan Kegiatan}

Alat dan bahan yang digunakan dalam kegiatan pengabdian ini adalah laptop, headset, aplikasi zoom, modul, powerpoint, proyektor, alat tulis, hand sanitizer, handphone, kamera, lighting, alat peraga (botol, plastik), sticker, poster, dan banner.

\section{Metode Pelaksanaan}

Program KKN-T Jakarta Timur 04 dilaksanakan di Aula Kecamatan Jatinegara dan diikuti oleh peserta UMKM Kecamatan Jatinegara, yang sudah bergabung di Jakpreneur Jatinegara. Tahapan pelaksanaan program ini terlihat pada Gambar 1. Pada bagian awal dilakukan focus group discussion (FGD) antara tim KKN-T Jakarta Timur 04 dan mitra, yaitu Jakprenuer Jatinegara. Hasil dari FGD ini adalah kesepahaman materi program yang dibutuhkan oleh anggota Jakprenuer Jatinegara, waktu pelaksanaan ke- giatan, calon peserta, dan tempat kegiatan. Sesuai dengan kebutuhan program maka bentuk kegiatannya adalah pelatihan yang dilakukan secara tatap muka, webinar via zoom, dan sosialisasi new normal, serta kampanye stop penggunaan kantong plastik. Pelatihan dilaksanakan untuk materi pencatatan keuangan, foto produk, canva, dan instagram, serta packaging produk. Materi pelatihan sudah disesuaikan dan disepakati oleh pihak mitra sesuai kebutuhan Jakprenuer Jatinegara.

Pelaksanaan kegiatan program KKN-T Jakarta Timur 04, dilaksanakan selama seminggu sekali untuk pelatihan di Aula Kecamatan Jatinegara, dan Aula Kelurahan Cipinang Cempedak, selain itu untuk pelaksaan sosialisasi new normal dilakukan di pasar binaan Jakprener Jatinegara yang terletak di Kawasan Pasar Bali Mester, Kawasan Pasar Rawa Bunga, dan Jalan Cipinang Jaya.

Metode Pengumpulan, Pengolahan, dan Analisis Data

Metode yang digunakan untuk mengumpulkan data, yaitu dengan cara menyebarkan kuesioner kepada seluruh peserta, setelah pelatihan selesai. Data dari kuesioner diolah secara deskriptif, menggunakan google form untuk mendapatkan hasil berupa diagram batang dan presentase.

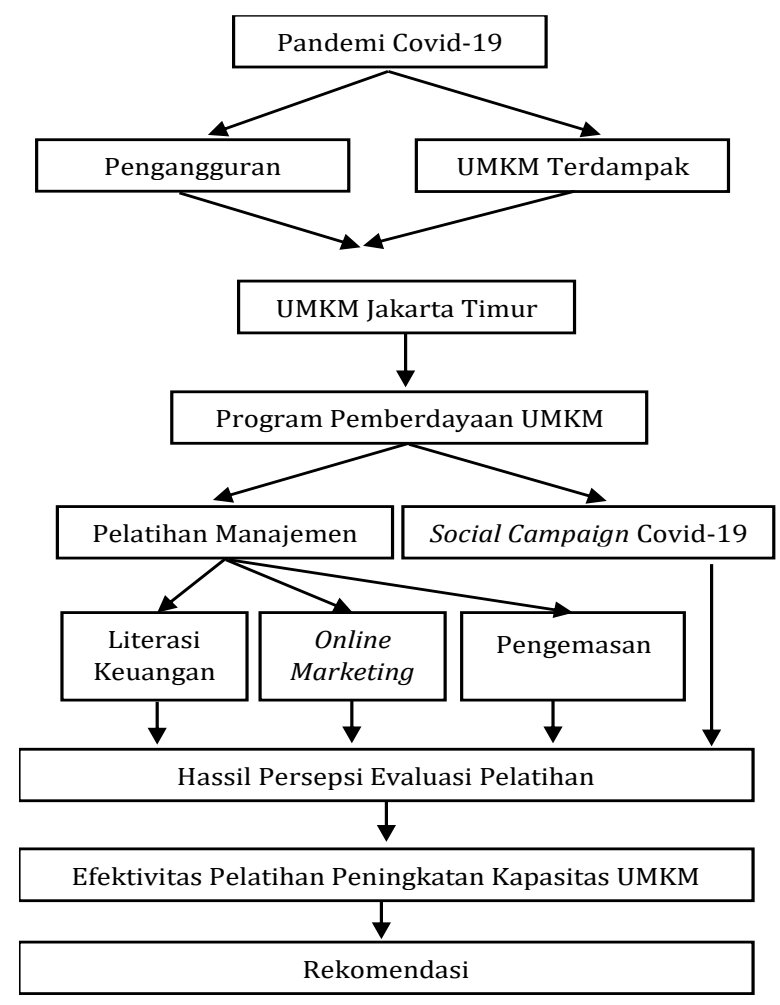

Gambar 1 Tahap pelaksanaan kegiatan. 


\section{HASIL DAN PEMBAHASAN}

\section{Webinar Strategi Mengelola UMKM dalam Membangun Daya Saing Berkelanjutan \\ - Deskripsi kegiatan}

Webinar strategi mengelola UMKM dalam membangun daya saing berkelanjutan merupakan program seminar online yang mengedukasi para pelaku UMKM untuk menjadi UMKM yang siap bersaing dalam era 4.0. Program ini terdiri dari tiga subtema, yaitu potensi, tantangan, dan strategi keberlanjutan UMKM di Kecamatan Jatinegara, pengelolaan menuju UMKM berdayasaing berkelanjutan, dan strategi mengelola keuangan UMKM pada masa krisis. Ketiga subtema tersebut disampaikan oleh narasumber yang berbeda dan ahli dalam bidangnya.

\section{- Pelaksanaan}

Kegiatan ini berlangsung pada tanggal 5 Agustus 2020 dari pukul 09.30-11.30 WIB melalui aplikasi zoom meeting diawali dengan sambutan oleh Bapak Camat Jatinegara setelah itu pembukaan oleh moderator, yaitu Kepala Satuan Pelaksana PPKUKM Kecamatan Jatinegara, kemudian dilanjutkan penyampaian kondisi terkini keadaan UMKM mengenai Potensi, Tantangan dan Strategi Keberlanjutan UMKM khususnya di Kecamatan Jatinegara, selanjutnya penyampaian materi pertama oleh dosen dari IPB dengan tema pengelolaan menuju UMKM berdaya saing berkelanjutan dengan poin utama materi adalah tips agar UMKM dapat bersaing secara berkelanjutan maka strategi yang dilakukan adalah 1) Konsisten menjaga mutu produk; 2) Menciptakan kemasan produk yang menarik; 3) Berani bersaing dari segi harga; dan 4) Menjaga loyalitas konsumen. Materi terakhir disampaikan oleh Bapak Gilman Pradana, SE, MM dengan tema strategi mengelola keuangan UMKM pada masa krisis. Tips dari pemateri bagi UMKM adalah terdapat hal-hal yang perlu diperhatikan saat krisis adalah dana darurat, arus kas yang selalu diperhatikan dan diupayakan positif, pentingnya proteksi keuangan, manajemen piutang dan inisiatif perubahan. Setelah penyampaian materi oleh keynote speaker dan para pembicara, acara dilanjutkan dengan sesi tanya jawab dengan peserta, kemudian penutupan oleh Dosen Pembimping. Dokumentasi kegiatan webinar strategi mengelola UMKM dalam membangun daya saing berkelanjutan terlihat pada Gambar 2 .

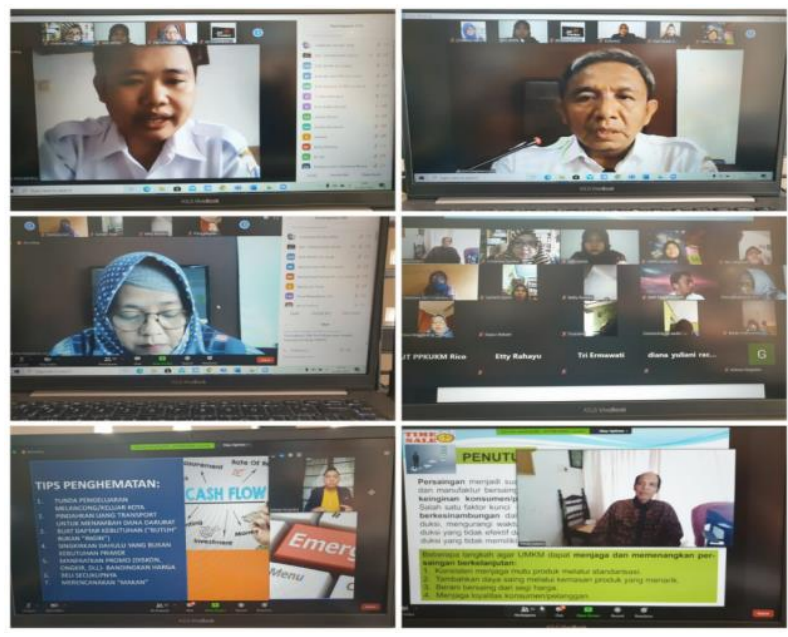

Gambar 2 Dokumentasi kegiatan webinar strategi mengelola UMKM dalam membangun daya saing berkelanjutan.

\section{- Hasil}

Sebanyak 60 pelaku UMKM di Kecamatan Jatinegara mengikuti webinar ini dan peserta memberikan ulasan yang baik dan teredukasi pada formulir kuesioner evaluasi yang diberikan. Kegiatan ini terlaksana berkat kerja sama dan dukungan yang sangat aktif dari pemerintah Provinsi DKI Jakarta khususnya Jakpreneur Jatinegara, sehingga acara tersebut berlangsung dengan lancar dan peserta webinar merupakan pelaku UMKM dengan berbagai jenis usaha khsususnya mayoritas di bidang kuliner sangat antusias mengikuti webinar.

Berdasarkan hasil kuesioner yang disebar kepada 60 peserta yang mengikuti webinar, terdapat 32 hasil kuesioner dengan rincian sebesar $96,9 \%$ paham tujuan dari webinar ini, sebesar $100 \%$ mendapatkan manfaat, dan sebesar 93,8\% menjawab isi webinar sesuai dengan usaha yang dijalani (Gambar 3).

\section{- Kendala}

Beberapa kendala pada kegiatan ini antara lain, peserta pelaku UMKM banyak yang tidak mengisi formulir pendaftaran dan tidak masuk ke dalam grup whatsapp yang telah dibuat untuk memudahkan dalam koordinasi terkait info webinar, peserta banyak yang tidak mengisi absensi pada hari acara berlangsung, keynote speaker tiba-tiba meminta untuk mengubah foto dalam poster webinar dan pada pagi hari sebelum acara berlangsung memberitahu secara tiba-tiba bahwa tidak bisa hadir dan digantikan oleh perwakilannya, penanggung jawab para 

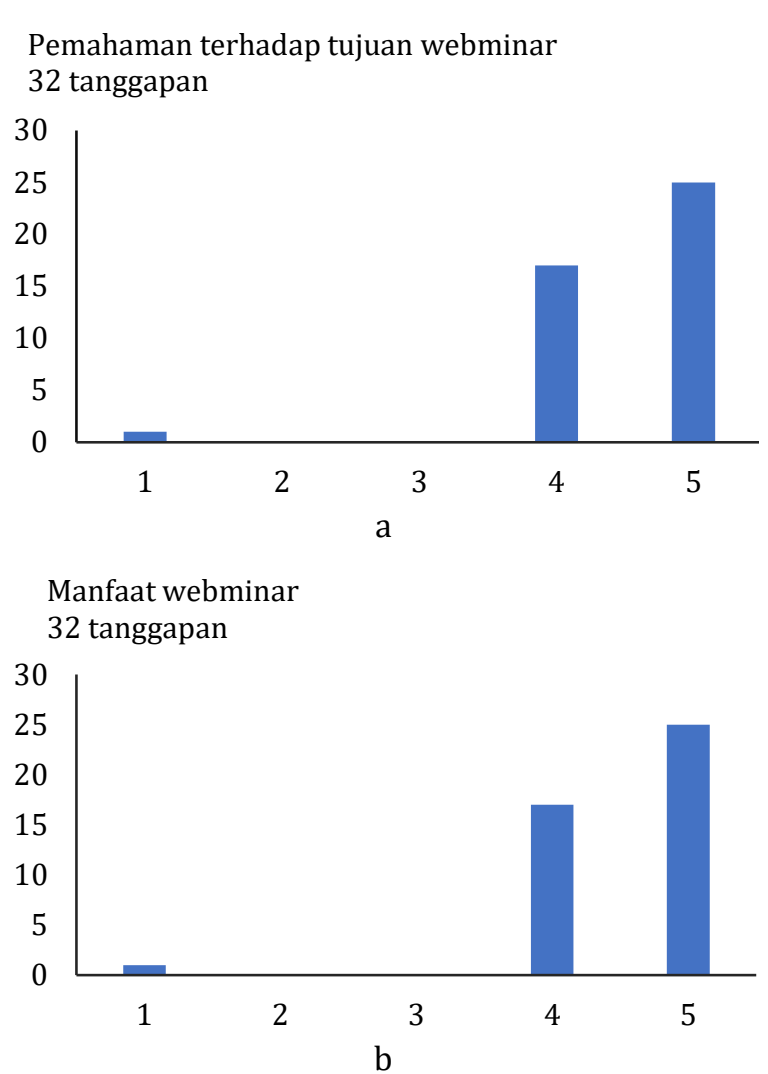

Kesesuaian webminar dengan usaha yang dijalani

32 tanggapan

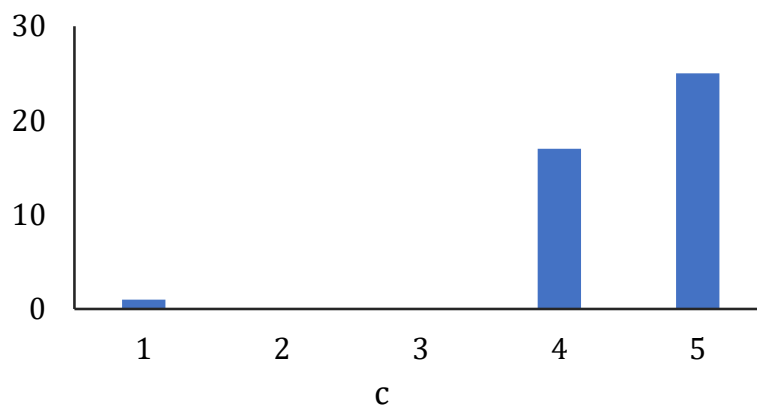

Gambar 3 Hasil kuisioner webinar strategi mengelola UMKM dalam membangun daya saing berkelanjutan: a) Pemahaman terhadap tujuan webminar; b) Manfaat webminar; dan c) Kesesuaian webminar dengan usaha yang dijalani.

narasumber lupa untuk meminta biodata diri para narasumber, MC diganti secara tiba-tiba karena tidak siap, signal moderator tiba-tiba hilang sehingga suaranya tidak terdengar dengan jelas, suara peserta sesekali terdengar saat acara berlangsung, dan sertifikat peserta baru dibagikan $\mathrm{H}+7$ acara.

\section{- Saran}

Lebih sering untuk mempublikasi acara ini di grup-grup UMKM, lebih sering untuk berkoordinasi dengan mitra Jakpreneur Jatinegara, memastikan para penanggung jawab tidak lupa untuk melaksanakan tugasnya, memastikan jadwal keynote speaker pada $\mathrm{H}-1$ acara, memastikan MC siap dan mengikuti rapat teknis sebelumnya, menyiapkan kondisi ruangan yang memiliki signal stabil untuk moderator, co-host zoom harus selalu siap untuk mute speaker para peserta, memastikan penanggung jawab sertifikat untuk segera membuat sertifikatnya.

\section{Pelatihan Pencatatan Keuangan \\ - Deskripsi kegiatan}

Pelatihan pencatatan keuangan merupakan pelatihan pertama dari seluruh rangkaian pelatihan yang ditujukan untuk mengedukasi pelaku UMKM di wilayah Kecamatan Jatinegara, Jakarta Timur agar dapat memahami dan menguasai pembukuan serta menulis laporan keuangan sehingga, dapat mempermudah akses pengajuan pembiayaan ke perbankan untuk meningkatkan skala usahanya.

\section{- Pelaksanaan}

Kegiatan pelatihan pencatatan keuangan telah berlangsung pada hari Selasa, tanggal 14 Juli 2020 di Aula Kecamtan Jatinegara dan dihadiri oleh 37 pelaku UMKM. Kegiatan pelatihan ini berlangsung secara tatap muka dengan tetap mematuhi protokol kesehatan di masa pandemi Covid-19, yaitu dengan menyediakan area cuci tangan bagi peserta sebelum memasuki ruang pelatihan, mengecek suhu tubuh, menggunakan masker, menjaga jarak, dan pembatasan peserta pelatihan. Pelatihan ini juga disiarkan secara langsung melalui aplikasi zoom. Acara diawali dengan pembukaan oleh pembawa acara, kemudian menyanyikan lagu Indonesia Raya, selanjutnya acara dibuka secara resmi oleh Wakil Camat Jatinegara. Setelah resmi dibuka, acara dimulai dengan sosialisasi Kredit Usaha Rakyat (KUR) oleh Bank Rakyat Indonesia (BRI), kemudian dilanjutkan dengan pemaparan materi pencatatan transaksi keuangan untuk usaha mikro dan kecil oleh pemateri. Pemaparan materi mencakup pengertian serta pembagian skala usaha mikro kecil menengah, perhitungan harga pokok produksi, dan pencatatan transaksi keuangan serta pembuatan laporannya. Acara dilanjutkan dengan sesi tanya jawab yang dipandu oleh pembawa acara, kemudian acara ditutup oleh Ketua Satuan Pelaksana PPKUKM Kecamatan Jatinegara, Jakarta Timur.

\section{- Hasil}

Sebanyak 37 peserta pelatihan pencatatan keuangan memberikan ulasan yang positif 
seperti terlihat pada Gambar 4. Berdasarkan hasil kuesioner yang diisi oleh peserta, rata-rata peserta telah memahami materi yang diberikan dan berharap akan terus ada pelatihan-pelatihan serupa. Kegiatan pelatihan ini terlaksana berkat kerja sama dan dukungan dari Satuan Pelaksana PPKUKM Kecamatan Jatinegara, Tim KKN-T IPB JakartaTimur04, dan bimbingan dari Dosen Pembimbing Lapang, sehingga acara pelatihan pencatatan keuangan ini dapat berlangsung dengan lancar dan mendapatkan antusias yang tinggi dari pelaku UMKM di Kecamatan Jatinegara, Jakarta Timur.

Pemahaman terhadap tujuan pelatihan 35 tanggapan

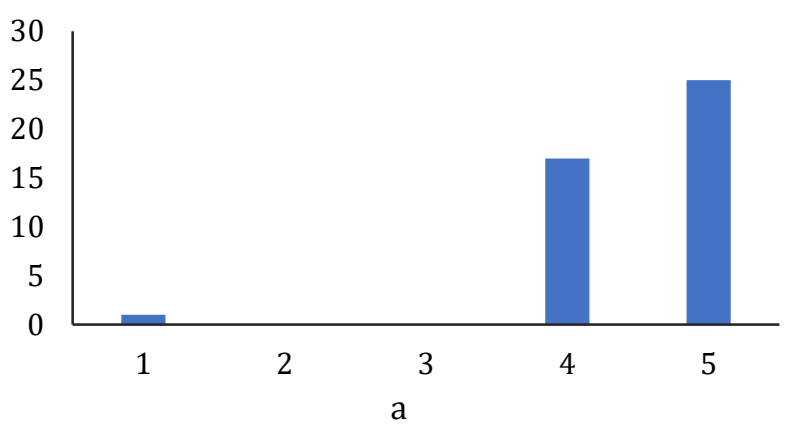

Manfaat pelatihan 35 tanggapan

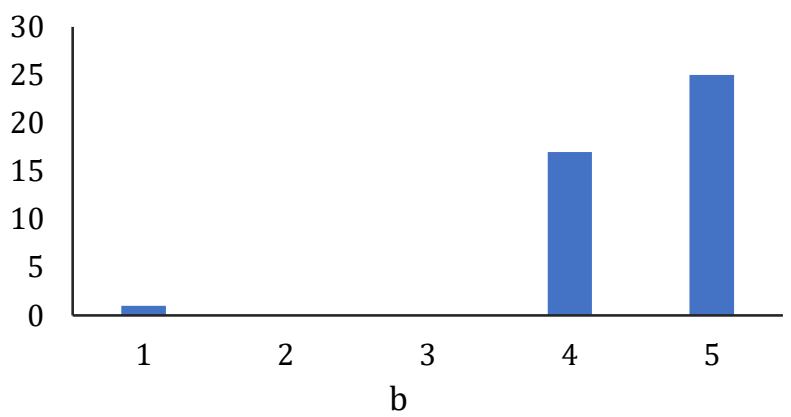

Kesesuaian pelatihan dengan usaha yang dijalani 35 tanggapan

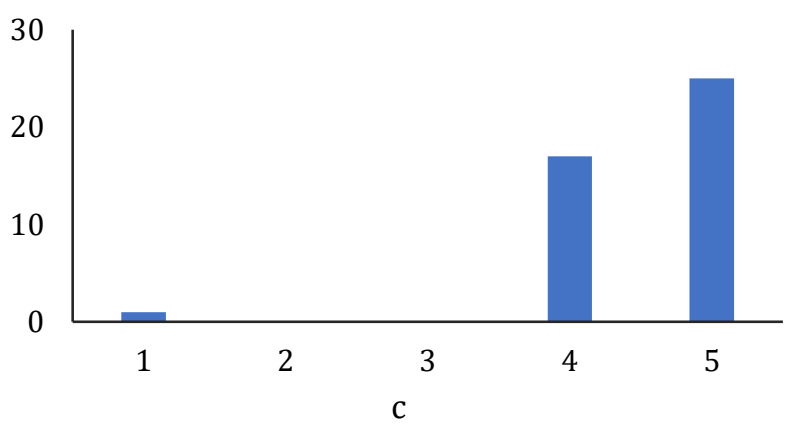

Gambar 4 Hasil kuesioner pencatatan keuangan: a) Pemahaman terhadap tujuan pelatihan; b) Manfaat pelatihan; dan c) Kesesuaian pelatihan dengan usaha yang dijalani.

\section{- Evaluasi}

Terdapat beberapa kendala yang dialami selama pelatihan pencatatan keuangan ini berlangsung, di antaranya adalah buruknya sinyal atau jaringan internet di lokasi pelatihan sehingga menyebabkan tayangan live zoom menjadi terganggu. Selain itu, kendala yang dialami berupa kendala teknis seperti layar proyektor yang kurang jernih dan ruangan yang panas karena air conditioner tidak berfungsi.

\section{- Saran}

Saran untuk kegiatan pelatihan serupa, sebaiknya kegiatan pelatihan pencatatan keuangan dilakukan dalam dua atau tiga sesi, sehingga peserta pelatihan dapat memahami lebih baik materi yang diberikan dan tidak merasa terburu-buru dalam belajar. Selain itu, perlu diadakannya pengecekan jaringan internet yang tersedia di ruangan pelatihan agar ketika hari pelaksanaan pelatihan tidak sulit dalam melakukan live zoom.

\section{Pelatihan Fotografi, Editing Foto, dan Penggunaan Instagram \\ - Deskripsi kegiatan}

Kegiatan pelatihan ini merupakan program KKN-T 2020 Jatinegara, yang memberikan pelatihan tentang aplikasi desain canva dan aplikasi instagram. Kegiatan ini menjelaskan kegunaan aplikasi canva yang berguna untuk membantu mitra dalam mendesain produk sehingga dapat bersaing di era modern dan memasarkannya di aplikasi instagram. Selain itu, juga menjelaskan kegunaan aplikasi instagram for business yang mendukung UMKM kecil dan fitur-fitur lainnya yang dapat membantu memasarkan produk UMKM.

\section{- Pelaksanaan}

Kegiatan ini berlangsung pada tanggal 22 Juli 2020 dari pukul 09.00-14.30 WIB di Aula Kecamatan Jatinegara diawali dengan pembukaan oleh pembawa acara (Mahasiswa IPB) lalu dilanjut sambutan oleh Bapak Camat Jatinegara setelah itu dilanjut dengan sambutan dari Kepala Satuan Pelakana PPKUKM Kecamatan Jatinegara. Acara dimulai dengan sesi pertama, yaitu pelatihan foto produk yang disampaikan oleh CEO PT. Karya Visual Anantara dengan alat bantu kamera, lighting, dan photobox, dengan poin utama adalah 1) Angle pada saat mengambil foto; 2) Komposisi cahaya saat pengambilan foto; dan 3) Fokus kamera saat pengambilan foto. Setelah 
pemateri selesai memaparkan materi maka dilakukan sesi tanya jawab sekitar 15 menit. Setelah selesai sesi pertanyaan, peserta istirahat dan kembali berkumpul di Aula Kecamatan Jatinegara pukul 13.00 WIB, selanjutnya sesi kedua tentang desain canva dan intsagram yang disampaikan oleh Mahasiswa IPB menjelaskan tentang tutorial cara penggunaan canva dan instagram untuk memasarkan produk mereka lebih baik, lalu dilanjutkan dengan sesi pertanyaan sekitar 15 menit, lalu acara ditutup oleh Ketua Satuan Pelaksana PPKUKM Kecamatan Jatinegara.

\section{- Hasil}

Sebanyak 43 pelaku UMKM di Kecamatan Jatinegara mengikuti pelatihan foto produk, desain canva dan instagram, serta para peserta sangat antusias mengikuti pelatihan ini karena langsung membawa produk dan langsung mempraktikkan cara memfoto produk dan menggunakan aplikasi desain canva dan instagram. Kegiatan ini terlaksana berkat kerja sama dan dukungan yang sangat aktif dari Pemerintah Provinsi DKI Jakarta khususnya Jakpreneur Jatinegara, sehingga acara tersebut berlangsung dengan lancar dan peserta yang merupakan para pelaku UMKM dengan berbagai jenis usaha dan mayoritas di bidang kuliner sangat antusias mengikuti pelatihan ini.

\section{- Evaluasi}

Peserta pelaku UMKM banyak yang terkendala ketika kamera di handphone mereka kurang bagus, sehingga pada saat pelatihan foto produk tidak dapat mengambil foto yang maksimal. Selain itu, beberapa handphone tidak memliki memori yang cukup untuk mendownload aplikasi canva dan instagram, dan para peserta terkendala jaringan internet yang kurang stabil dikarenakan mendesain menggunakan aplikasi canva membutuhkan internet yang stabil.
Selain itu, banyak peserta yang tidak melihat modul yang sudah diberikan dan hanya fokus terhadap proyektor, sehingga meminta bantuan kepada mahasiswa. Tim KKN-T Jatinegara juga kekurangan orang disaat para peserta meminta bantuan untuk mengoperasikan aplikasi canva dan instagram.

\section{- Saran}

Saran untuk kedepannya adalah harus menambah orang yang membantu peserta apabila terjadi kesulitan dalam mengikuti arahan pemateri, selain itu harus menggunakan bahasa semudah mungkin, karena peserta merupakan ibu-ibu yang notabene tidak terlalu mengerti bahasa teori. Menghimbau para peserta menyiapkan aplikasi sebelum pelatihan dan memastikan memiliki memori yang cukup untuk mengoperasikan aplikasi, karena akan mempengaruhi aplikasi.

\section{Pelatihan Pemasaran Digital \\ - Deskripsi kegiatan}

Kegiatan pelatihan ini merupakan program KKN-T 2020 Jatinegara, yang memberikan pelatihan tentang pemasaran digital, yaitu suatu usaha untuk mempromosikan sebuah merek dengan menggunakan media digital yang dapat menjangkau konsumen secara tepat waktu, pribadi, dan relevan. Tipe pemasaran digital mencakup banyak teknik dan praktik yang terkandung dalam kategori pemasaran internet salah satunya melalui platform pemasaran digital etalase88.com. Gambar 5 menunjukkan dokumentasi kegiatan pelatihan pemasaran digital.

\section{- Pelaksanaan}

Kegiatan ini berlangsung pada tanggal 29 Juli 2020 dari pukul 09.00-12.00 WIB di Aula Kecamatan Jatinegara. Kegiatan pelatihan ini berlangsung secara tatap muka dengan tetap mematuhi protokol kesehatan dimasa pandemi

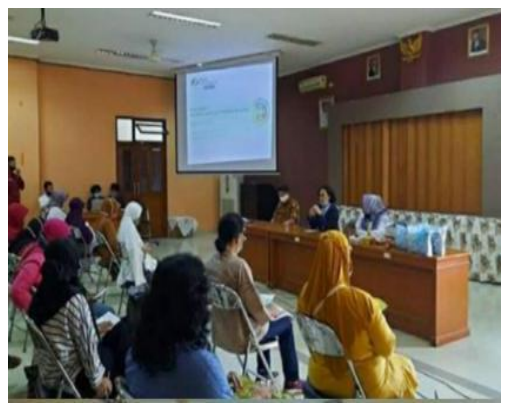

a

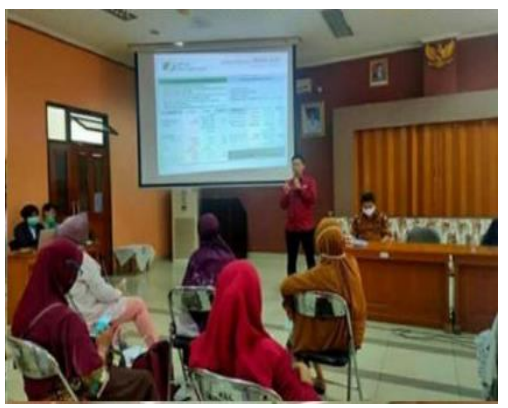

b

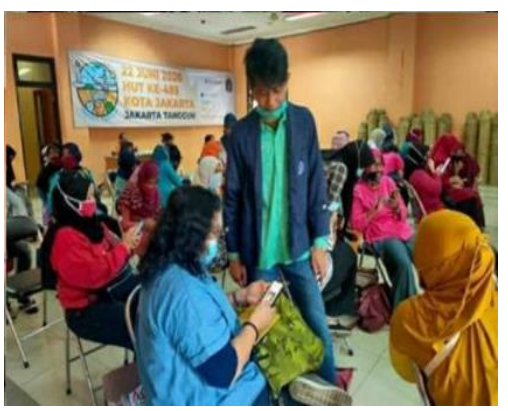

C

Gambar 5 a, b, dan c Dokumentasi kegiatan pelatihan pemasaran digital. 
Covid-19, yaitu dengan menyediakan area cuci tangan bagi peserta sebelum memasuki ruang pelatihan, pengecekan suhu tubuh, menggunakan masker, menjaga jarak, dan pembatasan peserta pelatihan. Pelatihan ini juga disiarkan secara langsung melalui aplikasi zoom. Kegiatan diawali dengan pembukaan oleh pembawa acara mahasiswa IPB, serta menyanyikan lagu Indonesia Raya. Kemudian dilanjutkan dengan sambutan oleh Camat Jatinegara setelah itu dilanjut dengan sambutan dari Kepala Satuan Pelakana PPKUKM Kecamatan Jatinegara. Acara dimulai dengan penyampaian materi oleh pemilik platform pemasaran digiral etalase88.com. Setelah pemateri selesai memaparkan materi maka dilakukan sesi tanya jawab sekitar 15 menit. Setelah selesai sesi pertama dilanjutkan sesi kedua, yaitu sosialisasi kenaikan manfaat program JKK (Jaminan Kecelakaan Kerja) dan JKM (Jaminan Kematian) oleh BPJS Ketenagakerjaan (Badan Penyelenggara Jaminan SosialKetenagakerjaan). Setelah sosialisasi selesai disampaikan kemudian dilakukan sesi tanya jawab selama 15 menit. Setelah sesi tanya jawab selesai kegiatan ditutup oleh Kepala Satuan Pelaksana PPUKM Kecamatan Jatinegara serta foto bersama dengan mengikuti protokol kesehatan.

\section{- Hasil}

Sebanyak 43 pelaku UMKM di Kecamatan Jatinegara memberikan ulasan yang baik dalam hasil kuesioner evaluasi yang dibagikan pada akhir acara. Kegiatan ini terlaksana berkat kerja sama dan dukungan dari Pemerintah Provinsi DKI Jakarta, khususnya Jakpreneur Jatinegara, Tim KKN-T IPB jakartatimur04, dan Dosen Pembimbing Lapang kelompok KKN-T IPB Jakartatimur04 sehingga acara ini berlangsung dengan lancar dan peserta pelatihan yang merupakan para pelaku UMKM dengan bidang usaha mayoritas di bidang kuliner sangat antusias mengikuti pelatihan ini.

\section{- Evaluasi}

Para peserta pelaku UMKM banyak yang terkendala ketika jaringan internet yang kurang stabil dikarenakan membuat toko di platform pemasaran etalase88.com membutuhkan internet yang stabil. Selain jaringan, platform pemasaran etalase88.com sendiri masih dalam tahap pengembangan sehingga setiap ada toko baru yang akan dibuat harus dikonfirmasi oleh pemilik platform tersebut di tempat sehingga proses pembuatan toko menjadi terhambat.
Kemudian banyak peserta yang tidak fokus terhadap proyektor dan pemateri yang sedang menjelaskan dan meminta bantuan kepada mahasiswa disaat hal yang ditanyakan sedang disampaikan oleh pemateri. Selain itu Tim KKN-T Jatinegara kekurangan orang disaat para peserta meminta bantuan untuk mengoperasikan platform pemasaran etalase88.com, dan juga dari tim KKN-T Jatinegara masih kurang paham mengenai platform pemasaran etalase88.com karena belum pernah mengoperasikan maupun menggunakan sebelumnya.

\section{- Saran}

Saran untuk kedepannya adalah harus menambah orang yang membantu peserta apabila terjadi kesulitan dalam mengikuti arahan pemateri, selain itu harus menggunakan bahasa semudah mungkin, karena peserta merupakan ibu-ibu yang notabene tidak terlalu mengerti bahasa teori dan teknologi. Kemudian sebelum akan dilaksanakannya kegiatan ini seharusnya dilakukan percobaan oleh tim KKN-T Jatinegara dalam menjalankan platform pemasaran etalase88.com agar dapat memahami sistem dan dapat membantu dalam menjalakan platform pemasaran etalase88.com.

\section{Pelatihan Packaging Makanan - Deskripsi kegiatan}

Pelatihan pemilihan kemasan untuk meningkatkan kualitas produk merupakan salah satu dari rangkaian pelatihan yang mengedukasi para pelaku UMKM, khususnya di daerah Jatinegara, agar dapat mengaplikasikan ilmu dan wawasan baru yang didapatkan untuk usahanya. Kegiatan pelatihan ini memiliki tema meningkatkan ketahanan produk dengan packaging yang baik.

\section{- Pelaksanaan}

Kegiatan ini telah berlangsung pada tanggal 12 Agustus 2020 dari pukul 08.45-11.30 WIB di Aula Kelurahan Cipinang Cempedak dan dihadiri oleh 45 pelaku UMKM. Acara ini dilangsukan secara tatap muka dengan tetap mengikuti protokol kesehatan di masa pandemi Covid-19, yaitu mencuci tangan sebelum memasuki gedung, menggunakan masker, dan menjaga jarak. Selain tatap muka, pelatihan ini juga disiarkan melalui aplikasi zoom. Acara diawali dengan menyanyikan Lagu Indonesia Raya dan dilanjutkan dengan pemaparan materi. Pemaparan materi tersebut mencakup karakteristik produk, faktor lingkungan yang perlu diper- 
hatikan, jenis bahan pengemas, tahapan memilih kemasan, dan kemasan untuk pengiriman. Acara dilanjutkan ke sesi tanya jawab dengan peserta terkait permasalahan yang kerap dialami oleh para pelaku UMKM dalam mengemas produk pangan yang dijual, seperti kemasan yang tepat untuk produk sejenis keripik, makanan siap saji, frozen product atau produk beku, kue, dan cookies, serta minuman. Kemudian latihan mengidentifikasi produk masing-masing hingga peserta dapat memilih jenis bahan kemasan yang tepat untuk mengemas produk tersebut dan menjamin keamanan serta kualitas isinya sampai ke tangan konsumen. Acara ditutup oleh salah satu anggota tim KKN IPB, yang mengajak para pelaku UMKM untuk mau berani melangkah maju mengembangkan usaha melalui beberapa tips seperti mencoba kolaborasi dengan beberapa pihak yang ahli, menerapkan ilmu-ilmu dari pelatihan yang didapatkan, serta mau belajar dengan tekun mendalami bidang yang dikerjakan.

\section{- Hasil}

Sebanyak 43 pelaku UMKM di Kecamatan Jatinegara memberikan ulasan yang baik dalam hasil kuesioner evaluasi yang dibagikan pada akhir acara. Kegiatan ini terlaksana berkat kerja sama dan dukungan dari Pemerintah Provinsi DKI Jakarta, khususnya Jakpreneur Jatinegara, Tim KKN-T IPB Jakartatimur04, dan dosen pembimbing lapang kelompok KKN-T terebut sehingga acara ini berlangsung dengan lancar dan peserta pelatihan yang merupakan para pelaku UMKM dengan bidang usaha mayoritas di bidang kuliner sangat antusias mengikuti pelatihan ini. Gambar 6 menunjukkan Hasil kuesioner pelatihan packaging makanan. Sebanyak 45 UMKM mengikuti pelatihan ini dan terdapat 43 hasil kuesioner dengan rincian sebesar 99,9\% mengerti isi pelatihan, sebesar $100 \%$ mendapatkan manfaat pelatihan, dan sebesar 97,6\% menjawab isi pelatihan sesuai dengan usaha yang dijalani.

\section{- Evaluasi}

Kendala yang dialami dalam pelatihan kali ini adalah adanya perubahan ruangan untuk penyelenggaraannya dari Aula Kecamatan Jatinegara menjadi Aula Kelurahan Cipinang Cempedak yang berada di lantai tiga. Lokasi tersebut agak sulit dicapai menggunakan tangga oleh para pelaku UMKM yang mayoritas adalah ibu rumah tangga. Selain itu, adanya keterlambatan absensi dan modul yang sudah dicetak untuk para
Pemahaman terhadap tujuan pelatihan

41 responden

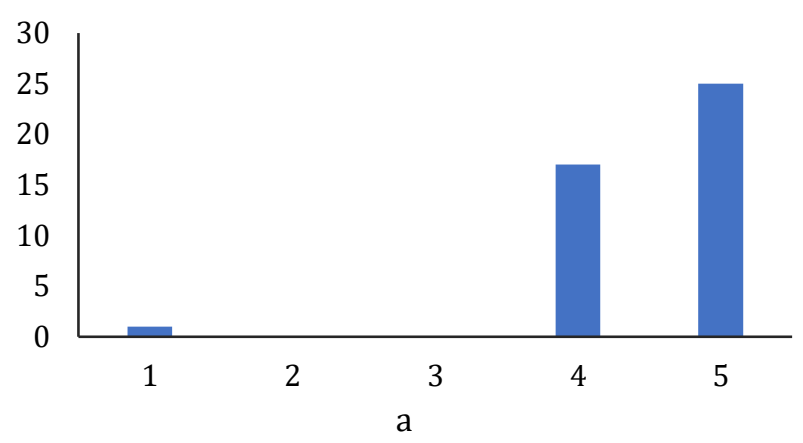

Manfaat pelatihan

41 responden

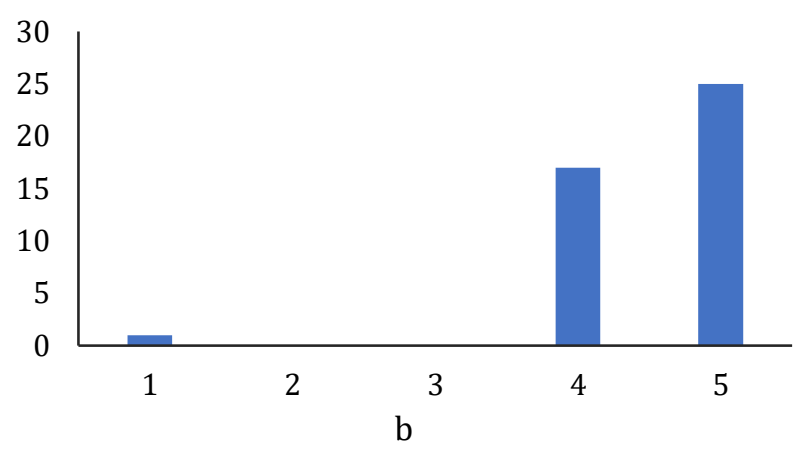

Kesesuaian isi pelatihan dengan usaha yang dijalani

43 responden

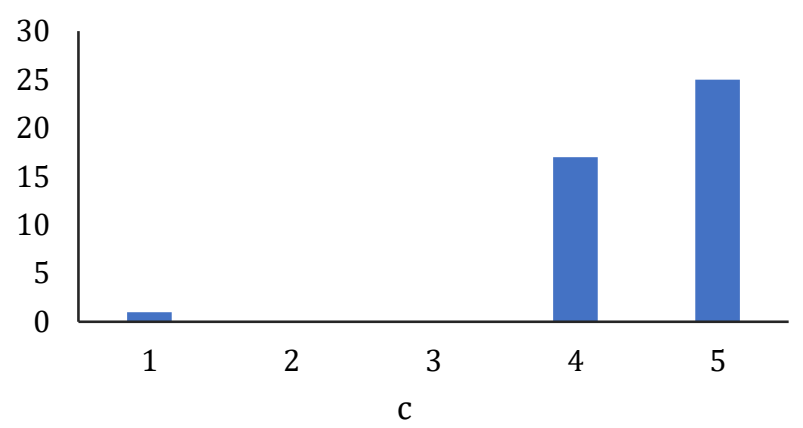

Gambar 6 Hasil kuisioner pelatihan packaging makanan: a) Pemahaman terhadap tujuan pelatihan; b) Manfaat pelatihan; dan c) Kesesuaian pelatihan dengan usaha yang dijalani.

peserta, pembicara terlalu cepat dan suaranya terlalu kecil dalam pemaparan materi, sinyal yang sempat hilang selama rekaman di zoom, serta sesi tanya jawab yang kurang kondusif karena para pelaku UMKM bertanya dari tempat duduknya sehingga kurang terdengar oleh seluruh peserta dan menyebabkan terjadinya pengulangan pertanyaan atau jawaban.

\section{- Saran}

Saran untuk kegiatan pelatihan serupa, yakni memfiksasi terlebih dahulu tempat untuk penyelenggaraan kegiatan dengan cara berkoordinasi 
dengan mitra, Jakpreneur Jatinegara, melaksanakan tugas sesuai tanggung jawabnya, mengecek sinyal yang digunakan untuk menyiarkan dan merekam di aplikasi zoom, menyiapkan presentasi atau pemaparan lebih baik lagi (perlahan, jelas, dan tegas), serta membuka beberapa sesi tanya jawab yang dipandu oleh pembawa acara agar lebih kondusif.

\section{Campaign New Normal \\ - Deskripsi kegiatan}

Campaign new normal merupakan salah satu program yang bertujuan mengajak masyarakat untuk menaati protokol kesehatan yang berlaku di masa adaptasi kebiasaan baru seperti penggunaan masker, anjuran untuk menjaga jarak (physical distancing), dan menjaga kebersihan diri. Kegiatan ini berupa sosialisasi langsung kepada masyarakat serta pemasangan poster dan stiker di pasar yang ada di kawasan Kecamatan Jatinegara.

\section{- Pelaksanaan}

Kegiatan campaign new normal berlangsung pada tanggal 15-17 Juli dan 20-21 Juli 2020 di lima lokasi usaha yang dibina oleh Satuan Pelaksana Dinas Perindustrian, Perdagangan, Koperasi dan UKM (PPKUKM) Kecamatan Jatinegara atau biasa disebut dengan JT. Kegiatan ini berupa sosialisasi langsung kepada masyarakat serta pemasangan poster dan stiker yang memuat informasi mengenai protokol kesehatan dimasa adaptasi kebiasaan baru. Sosialisasi pertama dilakukan pada hari Rabu, 15 Juli 2020 di JT08 yang berada di kawasan Pasar Mester. Hari berikutnya sosialisasi dilakukan di kawasan Pasar Rawa Bunga (JT09). Selanjutnya pada hari Jumat, 17 Juli 2020 sosialisasi kembali dilakukan di kawasan Pasar Mester, yaitu JT 10. Kegiatan sosialisasi dilanjutkan kembali pada hari Senin, 20 Juli 2020 di JT11 yang berada di kawasan
Pasar Mester dan pada hari Selasa, 21 Juli 2020 di Jalan Cipinang Jaya Raya. Kegiatan sosialisasi new normal ini dilakukan bersamaan dengan kampanye stop penggunaan plastik. Gambar 7 dokumentasi kegiatan campaign new normal di Pasar Mester, Pasar Rawa Bunga, dan Kuliner Jalan Cipinang Jaya.

\section{- Hasil}

Para pedagang cukup antusias saat kegiatan sosialisasi berlangsung. Mereka turut membantu dalam pemasangan poster dan stiker. Sebagian masyarakat di pasar sudah mematuhi protokol kesehatan dengan baik seperti memakai masker dan menyediakan tempat cuci tangan, namun masih ada beberapa pedagang di pasar yang belum mengetahui pentingnya mematuhi protokol kesehatan, salah satunya adalah menggunakan masker khususnya pada saat berinteraksi dengan pembeli. Kegiatan sosialisasi ini terlaksana dengan baik berkat kerja sama dan dukungan yang sangat aktif dari Satuan Pelaksana PPKUKM Kecamatan Jatinegara dan bimbingan dari dosen pembimbing lapang tim KKN-T Jatinegara.

\section{- Kendala}

Wilayah Jakarta Timur khususnya Kecamatan Jatinegara masih termasuk wilayah berstatus zona merah penularan virus corona sehingga kegiatan sosialisasi dilakukan secara terbatas demi menghindari kontak langsung dengan banyak masyarakat dan terjadinya kerumunan di pasar karena pasar tradisional dinilai menjadi salah satu tempat penularan virus corona. Oleh karena itu, tim KKN-T Jatinegara juga tidak melakukan peninjauan ulang ke lima lokasi usaha yang telah dipasang poster dan stiker.

\section{- Saran}

Kegiatan campaign new normal perlu dilakukan peninjauan ulang ke semua lokasi usaha

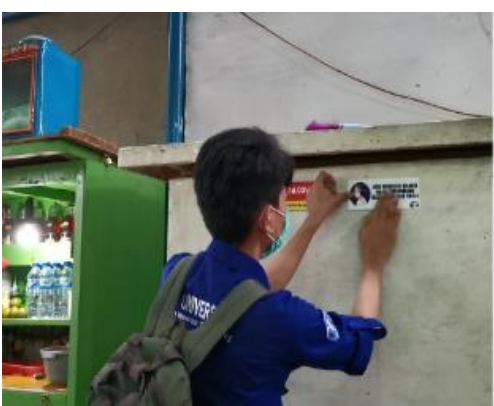

a

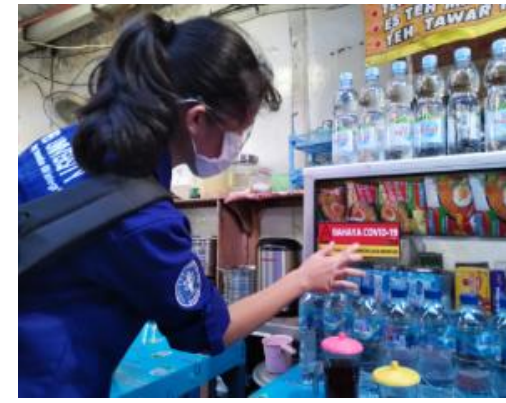

$\mathrm{b}$

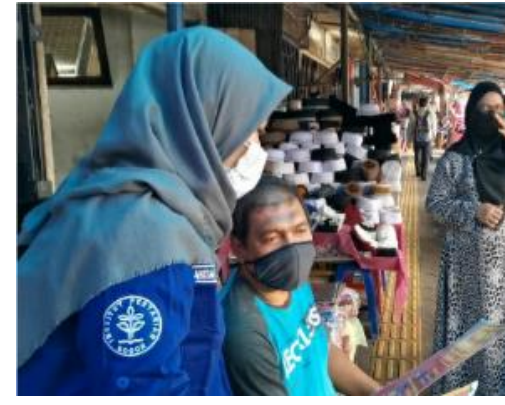

C

Gambar 7 a, b, dan c Dokumentasi kegiatan kampanye new normal di Pasar Mester, Pasar Rawa Bunga, dan Kuliner Jalan Cipinang Jaya. 
yang telah dipasang poster dan stiker untuk melihat perkembangan kepatuhan masyarakat dalam menjalankan protokol kesehatan di masa adaptasi kebiasaan baru.

\section{Kampanye Stop Penggunaan Kantong Plastik - Deskripsi kegiatan}

Kampanye stop penggunaan kantong plastik merupakan salah satu program yang bertujuan mengajak masyarakat untuk menaati Peraturan Gubernur DKI Jakarta nomor 142 tahun 2019, yaitu mulai tanggal 1 Juli 2020 Pedagang tidak lagi diperbolehkan menyediakan kantong plastik, sehingga pembeli/pengunjung pasar diharapkan bisa membawa kantong plastik sendiri. Kegiatan ini berupa sosialisasi langsung kepada para pedagang dan masyarakat yang sedang berada di pasar, serta pemasangan spanduk di lima pasar yang ada di kawasan Kecamatan Jatinegara.

\section{- Pelaksanaan}

Kegiatan kampanye stop penggunaan kantong plastik telah berlangsung pada tanggal 15-17 Juli dan 20-21 Juli 2020 pada lima lokasi usaha yang dibina oleh Satuan Pelaksana Dinas Perindustrian, Perdagangan, Koperasi dan UKM (PPKUKM) Kecamatan Jatinegara atau biasa disebut dengan JT. Kegiatan ini berupa sosialisasi langsung kepada para pedagang dan masyarakat yang sedang berada di pasar serta pemasangan spanduk yang memuat informasi mengenai Peraturan Gubernur DKI Jakarta nomor 142 tahun 2019. Sosialisasi pertama dilakukan pada hari Rabu, 15 Juli 2020 di JT08 yang berada di kawasan Pasar Mester. Pada Kamis, 16 Juli 2020 sosialisasi dilakukan di kawasan Pasar Rawa Bunga (JT09). Selanjutnya pada hari Jumat, 17 Juli 2020 sosialisasi kembali dilakukan di kawasan Pasar Mester (JT 10). Kegiatan sosialisasi dilanjutkan kembali pada hari Senin, 20 Juli 2020 di JT11 yang berada di kawasan Pasar Mester dan pada hari Selasa, 21 Juli 2020 di Jalan Cipinang Jaya Raya. Kegiatan kampanye stop penggunaan plastik ini dilakukan bersamaan dengan sosialisasi new normal.

\section{- Hasil}

Para pedagang maupun masyarakat cukup antusias saat kegiatan sosialisasi berlangsung. Mereka turut membantu dalam pemasangan spanduk dan cukup interaktif dengan menanyakan mengenai kebijakan tersebut. Tidak sedikit pedagang yang baru mengetahui Peraturan Gubernur nomor 142 tahun 2019 tersebut, bahkan ada yang menolak kebijakan tersebut dengan dalih plastik menjadi kebutuhan yang sulit untuk mereka hindarkan untuk keperluan berjualan. Tapi masih banyak juga pedagang yang mendukung program tersebut dengan harapan adanya kesadaran dari para pembeli untuk mau membawa kantong plastik sendiri. Kegiatan sosialisasi ini terlaksana dengan baik berkat kerja sama dan dukungan yang sangat aktif dari Satuan Pelaksana PPKUKM Kecamatan Jatinegara dan bimbingan dari dosen pembimbing lapang tim KKN-T Jatinegara.

\section{- Kendala}

Wilayah Jakarta Timur khususnya Kecamatan Jatinegara masih termasuk wilayah berstatus zona merah penularan virus corona sehingga kegiatan sosialisasi dilakukan secara terbatas demi menghindari kontak langsung dengan banyak masyarakat dan terjadinya kerumunan di pasar. Hal tersebut didasarkan karena pasar tradisional dinilai menjadi salah satu tempat penularan virus corona. Oleh karena itu, tim KKN-T Jatinegara juga tidak melakukan peninjauan ulang ke lima lokasi usaha yang telah dipasang spanduk dan dilakukan sosialisasi.

\section{- Saran}

Saran untuk kegiatan kampanye stop penggunaan kantong plastik ini adalah perlu dilakukan peninjauan ulang ke semua lokasi usaha yang telah dipasang spanduk untuk melihat kepatuhan para pedagang dan pembeli dalam penggunaan kantong plastik benar-benar dijalankan, tidak hanya dilakukan saat adanya sosialisasi saja.

\section{SIMPULAN}

Kegiatan pengabdian masyarakat dalam aspek ekonomi yang diterapkan di Kecamatan Jatinegara berupa pelatihan kepada para pelaku UMKM demi meningkatkan nilai usaha yang sedang dijalani mitra berupa pelatihan pencatatan keuangan dengan total 37 UMKM yang mengikuti pelatihan, diperoleh hasil, yaitu sebesar $91,4 \%$ peserta mengerti isi pelatihan dan sebesar 94,3\% mendapat manfaat dari pelatihan. Pelatihan foto produk, desain melalui aplikasi canva dan instagram diikuti sebanyak 43 UMKM, diperoleh hasil yaitu sebesar $62,5 \%$ paham dari tujuan pelatihan, sebesar $83,9 \%$ merasa bahwa pelatihan ini sesuai dengan bisnis atau kebutuhan yang sedang mereka jalani, dan 
sebesar 87,9\% mendapat manfaat dari pelatihan. Pelatihan pemasaran digital diikuti oleh 43 UMKM yang dikenalkan tentang e-commerce etalase 88 dan untuk Pelatihan pengemasan produk diikuti sebanyak 45 UMKM, diperoleh hasil yaitu sebesar 58,5\% mengerti isi pelatihan, sebesar 70,7\% mendapat manfaat dari pelatihan, dan sebesar 58,1\% merasa bahwa pelatihan ini sesuai dengan bisnis atau kebutuhan yang sedang mereka jalani. Pada aspek sosial yang dilakukan ialah edukasi untuk menurunkan kasus positif Covid-19 dan himbauan mengenai Peraturan Gubernur DKI Jakarta nomor 142 tahun 2019 tentang Larangan Pengunaan Plastik kepada masyarakat dan para pedagang yang ada di pasar binaan PPKUKM Jatinegara, yaitu pada JT 8, 9, 10 di Bali mester, JT 11 di Rawabunga, dan JT 17 di Cipinang Besar Selatan baik secara verbal maupun nonverbal (pemasangan spanduk dan stiker) di titik keramaian pada $5 \mathrm{JT}$ atau pasaar binaan PPKUKM Jatinegara tersebut.

Kecamatan Jatinegara, Kota Jakarta Timur diharapkan akan menjadi lokasi KKN kembali di kegiatan KKN selanjutnya sehingga programprogram yang telah dilaksanakan pada tahun ini dapat dilanjutkan kembali dan ditingkatkan seperti pada pelatihan pencatatan keuangan, diperlukan adanya praktik pembuatan laporan keuangan sampai menentukan laba/rugi dari usaha para peserta pelatihan. Lalu diberikan cara berjualan di instagram sehingga ilmu dasar tentang instagram sebelumnya bisa terealisasi untuk meningkatkan pendapatan dengan memperluas pasar para pelaku UMKM tersebut. Sehingga di tahun berikutnya masyarakat utamanya para pelaku UMKM dapat semakin berkembang sehingga pemulihan ekonomi pasca pandemi Covid-19 dapat berlangsung lebih cepat.

\section{DAFTAR PUSTAKA}

[BPS] Badan Pusat Statistik. 2019. Jumlah Penduduk Jakarta Tahun 2019. Jakarta (ID): BPS.

[BPS] Badan Pusat Statistik. 2020. Jumlah Penduduk Jakarta Tahun 2020. Jakarta (ID): BPS.
[Diskominfotik Jakarta] Dinas Komunikasi dan Informatika DKI Jakarta. 2020. Peta Persebaran Positif Covid-19 [Internet]. [dilihat pada 2020 Jul 1]. Tersedia pada: https://corona.jakarta.go.id/id/petapersebaran.

Han Y, Yang H. 2020. The transmission and diagnosis of 2019 novel coronavirus infection diseases (Covid-19): a Chinese perspective. Journal of Virology. 92(6): 639-644. https://doi.org/10.1002/jmv.25749

Jonathan J, Tjung LJ, Delianto B. 2019. Penataan Kawasan Segitiga Jatinegara sebagai ikon wisata Jakarta Timur. Jurnal Sains, Teknologi, Urban, Perancangan, Arsitektur. 1(2): 21912202. https://doi.org/10.24912/ stupa.v1i2.4593

Kurniawan D, Tjahjadi E, Simatupang W. 2018. Studi perubahan kegiatan perdagangan pada koridor komersial studi kasus: Jalan Raya Bekasi Barar. Jurnal Muara Sains Teknologi Kedokteran dan Ilmu Kesehatan. 2(2): 346$355 . \quad$ https://doi.org/10.24912/jmstkik. v2i2.867

Ren L, Wang Y, Wu Z, Xiang Z, Guo L, Jiang Y, Xiong Y, Li Y, Li X, Li H et al. 2020. Identification of a novel coronavirus causing severe pneumonia in human: a descriptive study. Chinese Medical Journal. 133(9): 1015-1024. https://doi.org/ 10.1097/CM9.0000000000000722

Susilo A, Rumende MR, Pitoyo CW, Santoso WD, Yulianti M, Herikurniawan, Sinto R, Singh G, Nainggolan L, Nelwan EJ et al. 2020. Coronavirus Disease 2019: tinjauan literatur terbaru. Jurnal Penyakit Dalam Indonesia. 7(1): $\quad 45-67 . \quad$ https://doi.org/10. 7454/jpdi.v7i1.415

Van Doremalen N, Bushmaker T, Moris DH, Holbrook MG, Gamble A, Williamson BN, Tamin A, Harcourt JL, Thornburg NJ, Gerber SI. 2020. Aerosol and surface stability of SARSCoV-2 compared with SARS-CoV-1. The New England Journal of Medicine. 382(1): 15641567. https://doi.org/10.1056/ NEJMc2004973 